Relations industrielles

Industrial Relations

\title{
The Application of the Collective Agreement and Personnel Administration
}

Jean Gagné

Volume 4, numéro 8, avril 1949

URI : https://id.erudit.org/iderudit/1023519ar

DOI : https://doi.org/10.7202/1023519ar

Aller au sommaire du numéro

Éditeur(s)

Département des relations industrielles de l’Université Laval

ISSN

0034-379X (imprimé)

1703-8138 (numérique)

Découvrir la revue

Citer cet article

Gagné, J. (1949). The Application of the Collective Agreement and Personnel Administration. Relations industrielles / Industrial Relations, 4(8), 73-74.

https://doi.org/10.7202/1023519ar
Résumé de l'article

Employers' attitude towards workers' unions as negotiating units of the collective labour agreement
Tous droits réservés @ Département des relations industrielles de l’Université Laval, 1949
Ce document est protégé par la loi sur le droit d'auteur. L'utilisation des services d'Érudit (y compris la reproduction) est assujettie à sa politique d'utilisation que vous pouvez consulter en ligne.

https://apropos.erudit.org/fr/usagers/politique-dutilisation/ 


\title{
THE APPLICATION OF THE COLLECTIVE AGREEMENT AND PERSONNEL ADMINISTRATION
}

\author{
Employers' attitude towards workers' unions as negotiating units \\ of the collective labour agreement
}

Jean Gagné

If we consider the administration of the extended collective agreement (decree), we know that the primary responsibility for the good application of the decree rests on the parity committee. The personnel manager can only serve as an interpreter, either to the benefit of the employer or the benefit of the employees, of the conflicts that may arise inside the enterprise, conflicts caused by a bad application of the decree. In this case, his role consists usually in the making of suggestions to the employees or to the employer. We have no intention of covering at length this aspect of the problem of administration of the decree as it depends on an organization which is outside of the business.

If in a commercial or industrial enterprise, labour relations are governed only by a particular collective agreement, the administration of the agreement creates new bonds and new responsibilities in the relations between employers and employees. Therefore the administration of the agreement introduces a problem of relations between the representatives of the administration of the enterprise and those of the workers' associations. The grievance committee or labour relations committee, usually formed under one of the clauses of the agreement, becomes the principal instrument in the hands of the representatives of the union to supervise the carrying out of the agreement. The grievance committee is certainly the best direct method that exists for diminishing the distance which separates the employers and the employees of the same enterprise and to prepare, at long range, the future negotiations which could be made in a spirit more friendly and more comprehensive of the needs of the workers and of the employers. In this way, one could perhaps secure better clauses in the future collective agreements. But we will not go into the importance or the functions of these grievance committees or the procedure for settling grievances.

We will therefore concern ourselves with the study of the problem which the collective agree- ment presents to the personnel manager. We believe that labour relations regulated by the clauses of a collective agreement can not only help the worker claim his rights and privileges in the enterprise, but also help the management in the administration of its personnel, and even be profitable for the enterprise from all points of view. We believe that all the problem, (if there is a problem) lies in the question of attitude of mind of the two parties to the agreement. And it is from this angle that we shall cover the subject.

The collective agreement has taken its place in the industrial habits of our day, whether we like it or not. It is necessary to know how it may be integrated into the work of the directors of an enterprise and of the personnel manager, because, it influences the way of administrating the enterprise and directing the personnel, and, more and more, plays the role of mediator between employer and employees. Therefore, it is necessary to understand that the collective agreement, in addition to being a wonderful instrument of negotiation of better labour conditions for the employees, has a value which can be turned into profits and industrial progress for the employers.

The first attitude that we shall examine is that of the employers towards the unions as negotiating units of the collective agreements. The employers can be divided into two categories. those which are against unionism and everything which goes with it, in theory or in practice or both at once and those which accept the fact of professional organization with its consequences.

Those of the first category try by their conduct to hurt as much as possible the development of workers' organizations. Their minds are prejudiced, especially when it comes to negotiating with the unions. They use any possible methods of obstruction to the requests of the employees in the negotiation of the agreement. They do not see what legitimate function the unions can play in the decisions to be taken in regard to the regulating of working conditions, fixing salaries, job 
analysis and merit rating, etc. They put up with these unions because they are obliged to, and try to get away from their interference by legal means.

Whereas those of the second category (of which several are representatives of large industries and commerce) - category consisting especially of important companies viz. railways, printing industry, construction, etc. - negotiate in good faith with the union members and have for many years. From this experience, they believe that it is possible to discuss with a union, salaries and working conditions with a view to a collective agreement that is reasonable and directed toward better disciplined labour relations, more peaceful, serving the interests of the employees and employers at the same time favouring the progress of the industry.

Evidently, there are different categories of unions or syndicates, each having their methods, their tendencies, their way of negotiating a collective agreement, and of administering it in conformity with their views. Experience has shown that the collective agreement, because of the various kinds of professional organizations can present some advantages and some disadvantages. According to some, the testimony is conflicting.

It is necessary therefore, to discover what must be the true direction of the relations which must exist between employers and employees in the application of the collective agreement. At the present time, one cannot yet say that the system of the extended collective agreement as well as that of the particular collective agreement, has produced only good results for industry, trade and public services. It would appear, however, in any case, that in our country, the system of collective agreements could not survive and really improve our labour relations unless certain real results are obtained, as much from the viewpoint of production and efficiency, as from the viewpoint of social progress.

On one hand, the employers do not negotiate with unions to support a theory or simply to favour the growth or strength of workers' unions. On the other hand, the workers' unions, through the position they occupy in the industrial and commercial world, have become for the employers an essential factor which affects the life and the advancement of industry and enterprise.

But this place that they have taken in the industrial life is only justified by the desire they must continually have, in the negotiation and application of the collective agreement, that both parties reach a better understanding of their rights and legitimate duties. Otherwise the management of enterprises and personnel managers would act contrarily to their professional ethics as labour relations experts, if they considered it from any other viewpoint. Owing to the responsibility of their functions, they must work in harmony with the representatives of organized labour and favour the achievement of this improved method of dealing with their employees through the medium of unions, in submitting to the clauses of a collective agreement, of a decree that is law, or both at the same time. If not, they will prevent real progress in the industry, divert the workers' groups from professional ends and oblige them to take refuge in an attitude which is far from the true spirit of cooperation, which is supposed to animate the two parties to the agreement.

And so we see that the attitude of the employers towards the workers' unions as units of negotiation of the collective labour agreement may bring peace or disorder in the world of industry, trade and public services. 